\title{
The Mapping of Dakwah Potencies in Supporting Rejang Lebong to be a Religious Regency
}

\author{
Hariya Toni, Hasep Saputra \\ Faculty of Dakwah, IAIN Curup, Bengkulu \\ hariyatoni79@gmail.com
}

\begin{abstract}
Islam is a religion of da'wah, which is a religion that advocates to followers to invite all people to believe, charity, create and organize life in accordance with Islamic values. Today, da'wah as a noble task in its implementation has not been managed professionally and measurable. On the other hand da'i has not been able to be a change agent as the ideals of Islam is rahmatan lil'âlamîn. Consequently the position of da'wah is less desirable because it has not been able to give a significant influence for the progress of the people. Therefore, comprehensive assessment and mapping of the strengths, weaknesses, opportunities and challenges of da'wah are required. This study offers the argument that a comprehensive mapping of the matter and then accompanied by professional planning and implementation of da'wah, professionally so the da'wah will be able to give influence and be a solution to various problems of people life in the current era of globalization.
\end{abstract}

Keywords: Mapping, da'wah, Rejang Lebong

\section{Introduction}

Da'wah of amar ma'ruf nahi mungkar practically has been going on since the interaction between God and His servant (the period of Prophet Adam AS), and will end with the end of life in this world. The da'wah of Islam as a manifestation of calling and bringing mankind to the way of Allah should basically start from the Muslims as the da'wah (ibda binafsika) actors before preaching to others in accordance with Allah's call: "Hi those who believe, protect yourself and your family from the punishment of hell .... " (Surah a Tahrim / 66: 6) The attempt to manifest Islam in life is done through da'wah by means of the good (amar ma'ruf) preventing evil deed (nahyu munkar), and invites to believe (tu'minuna billah) for the realization of a good community or khairu ummah (QS Ali Imran / 3: 104).

In the main, da'wah is a future-oriented and humanitarian activity, whether near or far away is the afterlife. The orientation of humanity is

AJIS : Academic Journal of Islamic Studies vol. 3, no. 1, 2018

IAIN Curup - Bengkulu | p-ISSN 2580-3174, e-ISSN 2580-3190

Available online: http://journal.staincurup.ac.id/index.php/AJIS 
done by developing life toward spiritual, socio-political and economic spiritual well-being. These efforts are based on the real conditions of the campus or the lives of different people and societies in widespread cultural realities. Unfortunately, da'wah is often separated from the real needs of human beings that should be the basis. Da'wah activities should be developed based on a detailed assessment of a community that will be made as the object of da'wah (mad'u).

Da'wah conditions in today's society seems to have gained fresh air changes. The Qur'an Educational Park for early age children, and the assembly ta'lim for adults either neighborhood activities or managed by the mosque is the first step for the progress and development of the next da'wah stage.

The position of Islamic da'wah in general can be seen from three perspectives, namely in terms of concept of da'wah, the potential of the muslims and the role of da'wah organization. First, in terms of concept, da'wah is the inherent character of Islamic teachings, namely between Islam with da'wah can not be separated. More firmly Sayyid Qutb says that Islam is a religion of da'wah ${ }^{1}$, a religion that obliges every Muslim to invite and convey the truth that comes from Allah swt, so that the value of the grace of Islam can blossom and grow in the life of the individual (shahsiyah), family (usrah), society and state (daulah). Da'wah is also the nature of nubuwwah, that is the nature of the Prophets and Messengers as a human choice is decided by Allah SWT. to invite human to the truth of the doctrine he brought (Surah 33: 45-46). Then the task is followed by the followers of the Prophet and this is also seen in the history of Islamic da'wah. The spread of Islam to all corners of the world, including to Indonesia by the merchants, is proof that the understanding of da'wah and the spirit of striving for the truth has been seared in every Muslim movement, whatever his profession. ${ }^{2}$ This is the power of da'wah in terms of concept.

1 Sayyid Quthb, Fî Zhilâl al-Qur'ân, vol. i (Beirut: Dâr al-Syuruq, 1986), p. 129. See, Ismail R. Al-Faruqi and Lois Lamya al-Faruqi, Atlas Budaya: Menjelajah Khazanah Peradaban Gemilang, Terj. Ilyas Hasan (Bandung: Mizan), h. 220, dan lihat juga, A. Mukti Ali, Beberapa Persoalan Agama Dewasa Ini (Jakarta: Rajawali Pers, 1987), h. 71. Selain Islam, agama Buddha dan Kristen juga disebut sebagai agama dakwah. Lihat misalnya Thomas W. Arnold, The Preaching of Islam, Terj. A. Nawawi Rambe (Jakarta: Wijaya,1985), p. 1.

${ }^{2}$ Hamka, Sejarah Umat Islam, (Singapura: Pustaka Nasional, 2005), p.681-682 
Furthermore, according to M. Natsir (1908-1993), da'wah in the broad sense is a duty that must be borne by every Muslim and Muslim mukalaf and nobody can avoid this obligation. ${ }^{3}$ According to him, da'wah based on al-amr bi al-ma'rûf wa al-nahyi 'an al-munkar is an absolute requirement for the perfection and safety of human life. Affirmed that the obligation as a bearer of human nature that always tends to the truth, in addition to humans as well as a social creature. If da'wah stops, then evil deed will be rampant.

Da'wah task is not only the responsibility of scholar, da'i and khatib, but the duty of each individual Muslim according to their ability, expertise and profession respectively. Scholars preach with the knowledge they have, both bi al-lisân and bi al-kitâbah. The ruler or government preaches with the powers and titles mentioned with the structural da'wah. While the martyrs (aghniya) preach with their possessions, namely preaching bi al-hâl. In addition, for people who have no knowledge, power and possessions, it is also required to hate every evil deed and he himself must stay away from it.

Understanding the concept of da'wah as described above, then accompanied by an operational form in the midst of community life, then this will really be a force for Islamic da'wah. Moreover, the realization is carried out in groups organized by organizations or agencies of da'wah and da'wah activities carried out by da'i in a broad meaning.

On the other hand, Islamic da'wah is not just limited to da'wah activities conducted by da'wah and da'i institutions towards the congregation or people called da'wah jamaah. But also known as the concept of da'wah fardiyah, which is done by da'i to one person or some people mad'uw informally. Da'wah fardiyah has several advantages and privileges compared to da'wah jammah. ${ }^{4}$ Da'wah fardiyah in its operations can take place anywhere, anytime and with anyone its mad'u, because it is not bound by the protocol event as has been discussed before this. Therefore, if da'wah is understood in a broad sense and become a common movement among Muslims, then this will be a force

\footnotetext{
3 M. Natsir, fiqhud Dakwah, (Jakarta: Media Dakwah), p.110

${ }^{4}$ Ali Abdul Halim Mahmud, Dakwah Fardiyah, terj. As`ad Yasin. (Jakarta: Gema Insani Press. 1995), p.30.
} 
for social change in accordance with the ideals of the Qur'an, so that the Muslim community becomes the best people (khaira ummah).

Second, the strength of da'wah is seen in terms of quantity and quality and potential of Muslims in Indonesia. The majority of Indonesia's population, which is $87 \%$ is Muslim, even the nation of Indonesia is the largest Muslim followers on earth. ${ }^{5}$ This condition on one side is a force for Islamic da'wah, if the potential, quality and participation of this majority can be mobilized, and used for the benefit of Islamic da'wah. The potential of political elites, economic elites and educational elites at every level of society needs empowerment. In contrast this majority, can also backfire, if not accompanied by adequate quality.

Political elites and rulers from among Muslims should be encouraged and asked to help and be responsible for the progress of da'wah. In fact the existence of political elites and rulers can change society more quickly. Its existence must play an important role, such as giving birth to laws or regulations that can protect people. According to Moh Ali Aziz, the result of political support has evolved sharia economy and the implementation of Islamic sharia in some areas of the country. However, political da'wah sometimes does not bring peace and tranquility among da'wah partners. ${ }^{6}$ For the future, there is still a need to increase the da'wah through political channels, because there are still many rights of Muslims that need to be struggled, such as halal law that has been 16 years has not been legalized, even though Indonesia is a predominantly Muslim country. While a minority of Muslims, such as Singapore already have the law.

Islamic da'wah will be strong, if the majority of people participate in supporting and assisting da'wah activities in accordance with the ability and respective profession. Therefore da'wah anfd da'i organization do not regard them as objects or targets of da'wah, but they must be positioned as da'wah partners and prepared, empowered and encouraged to be the subject of da'w or da'i. Process and called activity is da'wah development strategy. If they can not be expected to appear as the subject of da'wah, then at least participation and support for da'wah

5 Nurcholis Madjid, Islam Doktrin dan Peradaban, (Jakarta: Yayasan Wakaf Paramadina, 1992), p. 160.

${ }^{6}$ Moh Ali Aziz, Ilmu Dakwah, (Jakarta: Kencana Prenada Media Group, 2004), p.5. 
activities. The realization or not this depends on the ability of da'i and da'wah organization as the most important element in the da'wah system to improve the resources of the people.

Third, the power of da'wah is seen in terms of the existence of religious organizations in Indonesia which is engaged in the field of da'wah. The power of da'wah lies in the active role of religious organizations or Islamic organizations in Indonesia, that take part in da'wah. There is no single religious organization that does not participate in the field of da'wah. Da'wah in broad terminology covers the fields of politics, economy, social efforts, science and technology activities, art creations, codification of law and so forth. It is for a Muslim to be a tool of da'wah. ${ }^{7}$

Islamic religious organizations are older than this country, because they existed before Indonesia became independent. The largest religious organizations today are Muhammadiyah (1912), Nahdlatul Ulama (1926) and Al-Washliyah (1930). In addition, there are other organizations such as Mathla'ul Anwar, Ittihadul Muballighin, Al Irsyad and others. Muhammadiyah for example says that the problem of da'wah is very important. Because the intent and purpose of establishing the association is to uphold the religion of Islam so as to realize the true Islamic society. ${ }^{8}$

More specifically, the mass media presence of both print and electronic media is a logical consequence of the advancement of science and technology. According to Ibnu Hammad, the advancement of information and communication technology (ICT),especially telephones, computers and satellites that form cyber communication networks, information is now manifest in all forms (omniform, omniplace) and for various purposes (omnipurpose). ${ }^{9}$ The existence offers opportunities for da'wah activities or at least through mass media messages of preaching can reach the broader layers of society, for example through newspapers, radio, television and internet.

\footnotetext{
7 M. Amien Rais, Cakrawala Islam, (Bandung : Mizan, 1991), p.27.

${ }^{8}$ Syarifuddin Jurdi, 1 Abad Muihammadiyah, (Jakarta: Kompas Media Nusantara), p. 258.

9 Ibnu Hammad, Kata Pengantar, dalam Syarif Hidayatullah dan Zulfikar S. Dharmawan, Islam Virtual: Keberadaan Dunia Islam di Internet, (Jakarta: MIFTA, 2004), p. viii.
} 
To that end, Muslims, especially managers of da'wah and da'i organizations should be skilled at utilizing these media. Future efforts, whether academic, cultural or political, must take into account the development of audio-visual media and advanced communication technologies.

Today, the da'wah challenge seems to be getting tougher, especially the challenges resulting from the advancement of science and technology as well as the impact of the current of modernization and globalization. Although behind the challenge it also offers opportunities that must be utilized. The da'wah challenge can be differentiated to two things. First, the challenge is the excess or impact of scientific and technological progress and the downside of globalization. Second, the challenges that come from non-Muslim parties, both from domestic and abroad, the various programs and strategies that they do. Third, the challenge of da'wah resulted from various issues of nationality that give negative effect to da'wah activities.

While on the other hand, da'wah is also faced with the problem of poverty, especially the impact of the economic crisis, which has resulted in the Indonesian population is below the poverty line. In addition to the challenges or problems of apostasy and ghazwul fikr by non-Muslims and this should always be wary of. In the context of ghazwul fikr, there are various accusations from outsiders of Islam such as Islam developed with swords and wars, as well as accusations of Islamic religious terrorism.

The da'wah challenge at the national level is also very diverse. The Indonesian nation now is stepping from a humble agrarian life to industrial life. The process of industrialization and modernization, human beings can forget the essence of life and the dual function it employs, namely as a servant to Allah (abdun), as caliph and successor of the prophetic message. Humans can become technological worshipers, matter and to others. If this condition arises, the result will produce an industry that hails the technology, as well as arrogant mental attitude arises against the transcendent values offered by divine revelation. It will in turn lead to secular thought and attitude, both in terms of separation of religion and politics, and in the sense of human freedom from control or commitment to religious values. 
Islamic da'wah in the homeland does not have a clear and systematic mapping, especially in Rejang Lebong regency, consequently the progress of da'wah progresses is not maximal and many obstacles. Among the forms of da'wah in Rejang Lebong are Religious Lectures in Masjid / Mushala, Majlis Ta'lim, Tabligh Akbar, Friday Khutbah, Kultum, and so forth.

\section{The Map of Da'wah}

The map in general can be interpreted as a description of the location of the sea, the location of the mountain and so on. Understanding the map can be understood as follows:

a. Map has an understanding of the Map in English or can be interpreted as an image of the environment, location and geographic boundaries of a region in the form of graphics.

b. The map has an understanding as a description of the social, economic, political and religious conditions in the form of narrative or description supported by good figures in the form of tables or statistical data. ${ }^{10}$

According to Rejang Lebong District Office of Religious Affairs, the map of da'wah is a visual representation or description containing various information and data that can be taken into consideration to formulate a systematic and detailed da'wah activity plan about the region or geographical boundaries. This series of reporting is a product of da'wah management. ${ }^{11}$ Meanwhile, according to MUI, dakwah map is complete information about the objective condition of elements and components of the da'wah system for instance: raw input, conversion, out put, feedback, and environmental. ${ }^{12}$

So da'wah map is a description of an area that contains the potential from various points of view, depicted with certain symbols as the management of da'wah in a da'wah system for the achievement of mission ideals efficiently and effectively.

\footnotetext{
747

10 Poerwadarminta, Kamus Umum Bahasa Indonesia (Jakarta: Balai Pustaka, 2002), p.

${ }^{11}$ Kanwil Depag Prop. Jateng, op. cit

12 For comparison see the information of the Indonesian Ulema Council, Kerangka Acuan Penyusunan Peta Dakwah Nasional (Jakarta: Masjid Istiqlal Taman Wijayakusuma, 2004), p. 6
} 
At least mastered the map of da'wah, able to compile work plan, expertly analyze the potential data of the region, and carefully aiming target that has not been explored by ulama / kyai / da'i. Equally important is the ability to formulate and define media-based, printed and electronic material guidance by optimizing the socio-cultural strength of local communities.

Extension workers are also expected to not forget to compile and send the report of each counseling activity regularly and on time every month. The extension report will be part of the physical evidence of accountability, the report of the activity is also an instrument to measure the success rate and failure of information activities and the extension of Islam.

\section{Da'wah Islamiyah}

Islam is the religion that Prophet Muhammad brought, for all mankind until the end of time. Islam will not develop if its followers are not proactive in the effort of developing Islamic broadcasting.

In the effort of developing and broadcasting Islam, so to realize its teachings in the midst of human life is a da'wah business that is established, continuous, full of sacrifice and struggle. ${ }^{13}$

In principle Islamic da'wah has started since the first revelation or since the Prophet Muhammad SAW, was appointed Apostle until he died, crossed various times, from the period of Hulafar-rasidin, Banu Ummayah, Bani Abbasiyah, classical dynasty followed by future generations until now still continue and will not stop.

Dakwah activity is a process of ihtiyar conveying as well as invites to the message of Islamic teachings continuously throughout history, for that needed wise management, using argumentation of data and information with appearance (packing) good.

Dakwah messages should be able to provide guidance and life guides that cool the heart.6 Da'wah practitioners should pay attention to the managerial and the signs used as a reference to purify religious teachings according to the Qur'an and Hadith.

\footnotetext{
13 Fathiy Yakam, Menggapai Sukses Perjuangan Da'i, (Solo: Romadhoni, 1990), p. 14
} 
Islam as religion is the successor of the preceding prophet's treatises, especially celestial religions such as Judaism and Christianity. Islam is derived because of the distortion of religious teachings, either because of the loss of the source of previous religious teachings or the conversion of followers. In Christianity for example, until now has not found the original scriptures.

Because da'wah is an activity of amar ma'ruf nahi mungkar, da'wah does not always revolve around religious issues such as recitation or activities that are considered as other religious activities. There are at least three patterns that can be understood about da'wah.

\section{Cultural Da'wah}

Cultural da'wah is a da'wah activity that closely approaches Cultural Islam, namely: one approach that seeks to review the formal doctrinal link between Islam and the state. Cultural da'wah is da'wah approaching the object of da'wah (mad'u) with attention to socio-cultural aspects that apply to the community. As the previous muballighs had done (known as walisongo) where they taught Islam using local customs and traditions. This da'wah approach through culture that causes many people who are interested in Islam. Until now the cultural da'wah is still preserved by some Muslims in Indonesia.

\section{Political Da'wah}

The political da'wah is a da'wah movement that is done by using power (government); activists preach da'wah Islamic teachings so that Islam can be made ideology of the state, or at least every government or state policy is always colored with the values of Islamic teachings so that the teachings of Islam underlie the political life of the nation. The state is also seen as the most strategic da'wah tool.

The political da'wah is also called as a structural da'wah. The strength of this structural propagation generally lies in the doctrine that it propagates. Some Islamic groups are adamantly fighting for this kind of da'wah according to their understanding.

3. Economy Da'wah 
Economic da'wah is the da'wah activity of Muslims who try to implement Islamic teachings related to economic processes in order to improve the welfare of Muslims. The ecosnomic da'wah seeks to invite Muslims to improve their economy and prosperity. Islamic teachings in this category include; sale, purchase, order, zakat, expenditure and so forth.

The meaning of "da'wah" is also adjacent to the concept of ta'lim, tadzkir, and tashwir.Ta'lim means teaching, the purpose is to increase the knowledge of the people, the activity is promotive that is increasing knowledge, while the object is the person who is still lacking knowledge. Tadzkir means reminding with the aim of improving and reminding the people who forget his duty as a Muslim attack. Therefore, this activity is reparative or improving attitudes, and behaviors damaged by the influence of family and socio-cultural environment is not good, the object is clear those who are forgetting the duties and role as a Muslim.

Tashwir means to describe something in the mind of a person, the goal of generating an understanding of something through contamination or explanation. This activity is propagating, that is instilling religious teachings to humans, so they are influenced to follow it. ${ }^{14}$

There are several purposes in carrying out the task of dakwah. The required da'wah should be oriented towards these purposes:

1. Establish an Islamic society, just as the apostles of Allah who started their da'wah among the ignorant society. They invite human to embrace the religion of Allah, delivering Nyan's revelations to his people, and warning them of shirk.

2. Da'wah by making improvements to the affected Muslim community. Such deviations and various evil deed, as well as the neglect of the community against all obligations.

Maintaining continuity of da'wah among the people who have held on to the truth, through constant teaching, remembrance, purification of the soul, and education. 15

\footnotetext{
14 Wahidin Saputra, Pengantar Ilmu Dakwah, Jakarta: Pustaka Setia, 2011), p. 6.

15 Jum'ah Amin Abdul Aziz, Fiqh Dakwah; Studi atas Berbagai Prinsip dan Kaidah yang Harus Dijadikan Acuan dalam Dakwah Islamiah, (Solo: Karya, 2011), p. 45-46
} 
When it says "Islamic da'wah", then what is meant is "The final treatise revealed to the Prophet Muhammad as a revelation from God in the form of a book that there is no evil in it, either in front or behind, with his miraculous value, written in the manuscripts narrated from the Prophet Saw with Sand who is mutawatir, who read it worth worship"with such explanations, Islamic da'wah has several characters that distinguish it from other da'wah. There are several characteristics of which are:

1. Rabaniyah, meaning comes from the revelation of Allah SWT.

2. Wasathiyah, meaning middle or balanced

3. Ijabiyah, positive meaning in view of nature, human, and life

4. Waqi'iyah, meaning realistic in treating individuals and society

5. Akhlaqiyah, meaning loaded with the value of truth, both in the means and objectives

6. Syumuliyah, meaning whole and thorough in its manhaj

7. Alamiyah, is global

8. Syuriyah, based on the principle of deliberation in determining everything

9. Jihadiyya, meaning to keep fighting anyone who dare to hinder Islam, and prevent the spread of da'wah.

10. Salafiyah, it means maintaining originality in understanding and belief. 16

Da'wah will not succeed if a da'i does not surrender himself in totality to strive in the way of Allah. Successful da'wah is the da'wah that effectively guide people to amar ma'ruf and nahi mungkar. Many factors that support the success of this da'wah, among which are:

1. A deep understanding

2. Strong faith

3. A strong love

4. Perfect awareness

5. Continuous work

In order to achieve that noble goal, a Muslim must be willing to sell himself and his property to God, until he has nothing. He made the world only for his da'wah, in order to gain the success of the Hereafter, in

\footnotetext{
16 Jum'ah Amin Abdul Aziz, Fiqh Dakwah; Studi atas Berbagai Prinsip dan Kaidah yang Harus Dijadikan Acuan dalam Dakwah Islamiah, (Solo: Karya, 2011), p. 59
} 
retaliation for his sacrifice. Allah SWT says: "Allah has purchased from those who believe in themselves and their property by giving them a paradise (QS. At-Taubah: 111).

With the correct understanding of da'wah, we strive to implement this understanding to be incarnated in real life, and the principles carried out can be witnessed and perceived by humans. This is done through efforts to realize the following targets:

1. Ishlah An-Nafs (soul improvement), so that become a muslim strong physical, good morality, wide insight thinking, able to work, clean its belief, true worship and useful for others. This refinement leads to becoming human of wisdom.

2. Fostering Islamic households that impact on the harmonization of life within the scope of the family and society at large.

3. Irsyad Al-Mujtama '(giving direction to the community) that is by inculcating the principle of amar ma'ruf nahi mungkar.

4. Da'wah to the government to apply the Shari'ah of Allah with all methods are wise and morality islamic

5. Da'wah to realize the unity of Islam by way, for instance consolidating to Islamic countries.

The way to realize that noble goal is in the following way:

1. Through da'wah delivered with wisdom (wise), good advice, and also denial with the good

2. With an Islamic education that holds the Qur'an and the teachings of the Prophet.

3. The building of Islamic education is where they are educated with Islamic education.

\section{Indicators of Map Da'wah}

Given the extent of the study in the map of da'wah, then the indicator is needed as a reference for the preparation of da'wah map, the indicator of da'wah map can be classified as:

1. Geographic description, including:

a) Data collection on the condition of Banyumanik Sub-district.

b) Overview of territory.

c) An overview of the condition of the land.

2. Demographic features, including: 
a) An overview of the population by age and sex.

b) The description of the population according to their livelihood.

c) A description of the state of education according to the stage.

3. The description of religious life, including:

a) Description of the state of the population by religion and its distribution.

b) A description of the place of people's worship of the people and its distribution.

c) A description of the general meeting place (meeting hall) and governmental devices.

4. The description of the implementation of Da'wa, including:

a) description of the state of da'wah activities either the subject of da'wah or human resources of da'wah; da'i and Object da'wah or Mad'u.

b) description of media, method, reference book (material) and implementation of da'wah management function used by the subject of da'wah or human resources of da'wah; da'i to Object Da'wah or Mad'u, in the implementation of da'wah activities.

5. The picture of religious organization relate with the activities of Da'wah.

The classification of the banyumanik subdistrict in four levels of da'wah in the form classification is very good, growing and less developed which then visualized with the color on the map of the banyumanik sub-district. The colors are visualized with a green, yellow, pink, and red look, with this visualization easily known priority areas that will become da'wah area.

Visualization is useful to determine da'wah strategy for the subject and object of dakwah that exist in banyumanik sub-district. From the visualization will facilitate in providing an overview of the potential and social situations in the form of narrative with the supported numbers and tables that relate with da'wah.

In the arrangement that will be done there are 3 principal work that becomes the determinant for da'i to achieve success da'wah in a region.

1. Structural, the ideal structure is: 
a) The structure created can accommodate the needs of human resources (HR) da'i and region.

b) The existence of the highest policy makers as command and can provide solutions to the problems that occur.

c) There is a clear division of duties and responsibilities to the personnel in the structures created.

d) Prepare and implement the program activities in the structure.

2. Structuring HR da'i, ideal human resources are:

a) HR gets its rights in accordance with established manpaj da'wah

b) HR can perform its duty to charity jama'i fairly.

c) HR enjoy comfort in da'wah, as long as the human resources intended has carried out its obligations.

d) human resources can develop themselves both the development set by the congregation and development based on individual considerations as long as it does not have negative effects for da'wah.

3. Arrangement of Da'wah Area, an ideal da'wah area are:

a) Each region has a da'wah concept defined by the policy holder in that area.

b) Each region obtains adequate allocation of resources.

c) The existence of autonomy in the arrangement of the area given to certain da'i / group da'i

d) In the territorial arrangement should consider the development of potential / local resources of the region concerned.

e) There is a network of da'wah that can access all elements of community preaching.

\section{Forms of Da'wah in Rejang Lebong Regency}

1. Ta'lim Assembly

Ta'lim Assembly is one of the non formal education institutions that aims to improve faith and piety to Allah SWT and noble character for the congregation, and realize the grace for the universe. 
In practice, ta'lim assembly is the most flexible and time-bound place of teaching or religious education of Islam. Ta'lim Assembly is open to all age, layer or social strata, and gender. The timing of the event was not tied up, could be morning, noon, afternoon, or night. where teaching can also be done at home, mosque, building, hall, page, and so on. In addition ta'lim assembly has two functions at once, namely as da'wah institutions and non-formal education institutions. Flexibility of the assembly ta'lim this is a force that can survive and is the Islamic educational institution that is the closest to the people (community).

Ta'lim assembly is also a vehicle for strong interaction and communication between ordinary people with the muslims, and between fellow members of the assembly ta'lim without limited by time and place.

Thus the ta'lim assembly become an alternative religious education institution for those who do not have enough energy, time, and opportunity to study the religion extends formal education. This is what makes ta'lim assembly has its own characteristic value compared to other religious institutions. ${ }^{17}$

\section{Remaja Masjid (Islamic Youth of Mosque)}

That is an organization or a collection of Muslim teenagers who use the mosque as a center of activity. Teens Mosque is one of the best teenager coaching alternatives. Through this organization, they gain an Islamic environment and can develop creativity.

Islamic Youth of Mosque build their members to believe, knowledgeable and do good deeds in order to serve Allah Subhanahu wa ta'ala to achieve His bless. Coaching is done by preparing various programs that are followed up with various activities. The established youth of mosques are usually able to work in a structured and planned manner. They compile the Periodic Work Program and perform various activities that are oriented towards: Islamic, mastery, youth, skills and scholarship.

17 Ta'lim Assembly is a non formal education institution whose existence is recognized and regulated in (1) of Law number 20 year 2003 concerning national education system; (2) Government regulation number 19 of 2005 challenges national education standard; (3) Government Regulation number 55 year 2007 concerning religious education and religious education; and (4) Decree of Supreme Court Number 3 Year 2006 regarding Strutur of Religious Department in 2006. 
They also do the job hearing based on the needs of the organization, in order to work effectively and efficiently. Several areas of work are formed to accommodate the organizational functions tailored to the Work Program and activities to be held, including:

a) Administration and Secretariat.

b) Finance.

c) Member Coaching.

d) Library and Information.

e) People's Welfare.

f) Womanhood.

As we have seen, that Youth Mosque is an organization that bring together active Muslim teenagers to come and worship in congregation Moses. Because of his attachment to the mosque, his main role is none other than prospering the mosque. This means, activity-oriented mosque has always been the main program. In performing its role, the youth of the mosque places priority on the activities of improving the faith, science and skills of its members.

Youth Activities A good mosque is done in a planned, continuous and wise way; besides it also requires appropriate strategies, methods, tactics and techniques. To arrive at such a good activity, at this time needed a good understanding of organization and management as well. The types of activities of Youth Mosque are:

a) Participate in prospering the mosque.

b) To coach Muslim youth.

c) Organizing the process of regeneration.

d) Providing support for Ta'mir Mosque activities.

e) Implementing da'wah and social activities.

\section{Kultum}

The seven-minute lecture is art, that is, the art of conveying something to the crowd with a short amount of time, which is only seven minutes as the name implies; kultum. Kultum then called people with a brief lecture that only discussed a few things from the problematic religion or just a reminder just so that people do not neglect on religious matters or problems that are good. In some societies, the habit of kultum is usually performed after each time to pray five times. 
But it turns out there is some time that is also commonly used to perform the kultum, one of which is at the time to start tarawih prayer in Ramadan with the intention while waiting for other congregations to come. Whenever its use, kultum remains a thing that can not be considered trivial, because often just because asked to speak this brief, people have a deep psychic disorder or in other languages is exposed to stage fright. The person looks cold hot before climbing the podium and this makes his speech not allegedly digress to and fro.

The message to be conveyed becomes blurred and the short time it felt the listener become boring because it feels long. Again not easy to do kultum. Need meaning and strategy that telling for our appearance calm so short message of kultum can be long in mind of listeners. Because the kultum that in practice not only done for seven minutes, but rather is a means of one-way communication, all eyes and ears of pilgrims / listeners are on us. It would be better if you really understand the ins and outs in doing the kultum.

\section{Tabligh Akbar}

Activities Tabligh Akbar is a concept to build communication in the framework of hospitality among fellow parishioners. In terms of giving and sharing of religious knowledge on certain conditions and situations. It means sharing and giving about goodness and righteousness, so it is not surprising that the activity is filled with religious lectures which is directed by teachers, both local and national teacher (ustaz). Thus, Tabligh Akbar is actually an effort to build a unity of people to communicate intellectually, spiritually and socially between each other, so that the purpose of religion and social goals can be realized properly.

Tabligh Akbar is also an effort to build unity of the people both in upholding religious sharia as well as in building social commitment. Tearing this understanding is not a few appear certain elements and certain political parties use the term Tabligh akbar to build imaging or community support for the interests of practical politics only. Well, If this happens then the value of Tabligh Akbar will shift to the real value, and not the reward and unity that we get but suspicion and division among the people. Why not? Because religion has been used as a political tool. This concept is what we need to avoid together. Therefore, there needs to 
be good intentions from all parties, both the executing committee, the community and the government to build a commitment and consistent, There is no indication and conspiracy other than to realize the unity.

\section{Mapping Da'wah in Rejang Lebong}

Da'wah is the activity of socialization and institutionalization of Islamic teachings as well as efforts to improve the lives of mankind in accordance with the demands of Islamic teachings, to be dealt with seriously and professionally. In its activities da'wah must start from social change and objective condition of life of society. To obtain a clear picture about the field of da'wah, it can be pursued through research and review of the implementation and formulation of da'wah used today. Another thing that is also quite important to do mission research periodically and true before da'wah activity done, there has been clarity about da'wah map.

Da'wah map is a systematic and narrative depiction of a social reality in the midst of society, which will be the field of da'wah. The description includes the social, economic, cultural, political and other situations. Then also concerning natural resources (SDA) and human resources (HR) and the depiction of the priority of da'wah issues that need immediate handling. ${ }^{18}$ The weakness of da'wah so far, because there is no da'wah map that provides an objective picture of the things mentioned above. Because of that activity da'wah often experience conflicts which in turn become an obstacle to the progress of Islamic da'wah.

In addition, research and thought and intelligent not only focus on da'wah object, but must be comprehensive to da'wah system, namely: da'i, mad'u, material, method, media and organization of da'wah. Furthermore, organizers of da'wah and da'i organizations are required to understand well about the strengths, weaknesses, opportunities and challenges of da'wah. From that understanding will be born an attitude to harness the strengths and opportunities and can suppress and anticipate against the weaknesses and challenges. p. 245

18 Abdul Munir Mulkhan, Paradigma Intelektual Muslim, (Yogyakarta: Sipress. 1993), 
In facing the progress of science and technology and the impact of globalization, then the da'i and da'i managers must have the courage to review the concept and implementation of da'wah today. Furthermore, it is necessary to reformulate the concept of da'wah which is adapted to the development of science and technology. If that is not done, then da'wah will be left behind from social progress of society.

Counseling of non-civil religion of Islam in the field are expected to be the front guard in order to assist the KUA and the Ministry of Religious Affairs in developing the community, and always uphold the image of the Ministry of Religious Affairs of Rejang Lebong Regency, since the function of religious instructors is informative, educative, consultative and functional advocative.

Nowadays, the religious counselors of Islam must be ready to deal with a state of rapid change in society leading to functional society, technological society, scientific society and open society. Thus, every religious counselor continually needs to increase knowledge, insight and self-development.

So the map of da'wah and report can be formulated appropriate and effective da'wah format and system for a certain community, a counselor in performing its duty is not like entering new and foreign territory.

This is the main provision for a professional and qualified religious instructor, all stakeholders later when this da'wah map has been well compiled will feel the ease with the accurate data so that systematic steps to improve society in the future will be achieved.

Da'wah in Rejang Lebong is carried out in mosques in each region or village, such as ta'lim assembly, risma, and kultum, and also there is da'wah which is cooperation between STAIN Curup and Government of Rejang Lebong area, such as jum'at safari, ramadan safari, and also jum'at blessing.

Activities at the mosque including mushalla or langgar in Rejang Lebong:

1. Ta'lim Assembly; ta'lim AssemblyIn Rejang Lebong district there are 359 ta'lim assemblies scattered in various mosques and 
mushalla. ${ }^{19}$ Which consists of 779 jama'ah men and about 900 people jama'ah women. Majelis ta'lim in Rejang Lebong district is usually held on Friday after the Friday prayers, and filled with religious lectures by religious teachers and ustazah in Rejang Lebong. The studies vary as to the problem of fiqh women, prayer, zakat, the problem of inheritance, family problems, talaq, and so forth.

2. Remaja Masjid (Islamic Youth of Mosque, in short risma); risma in Rejang Lebong Regency is also filled with religious activities, such as fiqh, worship, association, ethics, morals, and so forth. Risma in Rejang Lebong Regency is not as much as the growth of ta'lim assembly, due to several factors, namely the lack of initiative from the mosque board to establish Risma, and the laziness of adolescents to follow Risma because most of them come from public schools so the desire to study religion becomes less.

3. Kuliah Tujuh Menit (in short kultum); kultum is carried out by several mosques and government agencies when after the zuhur prayer or in the morning after the dawn prayer, the cult is usually filled by the da'i who are deliberately invited to deliver religious sermons.

Among the names of da'i registered at the Ministry of Religious Affairs of Rejang Lebong Regency are:20

\begin{tabular}{|c|l|l|l|}
\hline NUM & \multicolumn{1}{|c|}{ NAME } & \multicolumn{1}{|c|}{ ADDRESS } & \multicolumn{1}{|c|}{ POSITION } \\
\hline 1 & Drs. HM. Ch Naseh, M.Ed & S. Sukowati & $\begin{array}{l}\text { Head of Ministry of Religion } \\
\text { Affairs RL }\end{array}$ \\
\hline 2 & Drs. H. Nasril & Sukaraja & Head of MUI RL \\
\hline 3 & Drs. Damanhuri Anwar & Air Rambai & Pensioner \\
\hline 4 & Drs. H. Mawardi MS & Dusun Curup & Pensioner \\
\hline 5 & $\begin{array}{l}\text { Drs. Akhmad } \\
\text { Hafizuddin, M.HI }\end{array}$ & Talang Benih & $\begin{array}{l}\text { Office of Religion Affairs } \\
\text { North Curup }\end{array}$ \\
\hline 6 & Drs. H. Senopati & Tunas Harapan & Pensioner \\
\hline 7 & Drs. Kadar Najmiddin & Talang Benih & $\begin{array}{l}\text { Ministry of Religious Affairs } \\
\text { RL }\end{array}$ \\
\hline
\end{tabular}

${ }^{19}$ Document of Ministry of Religious Affairs, Rejang Lebong Regency of Bengkulu.

20 Document of Ministry of Religious Affairs, Rejang Lebong Regency of Bengkulu. 
Hariya Toni, Mapping of Da'wah | 61

\begin{tabular}{|c|c|c|c|}
\hline 8 & Drs. Suhardihirol, M.Pd & Teladan Village & $\begin{array}{l}\text { Ministry of Religious Affairs } \\
\text { RL }\end{array}$ \\
\hline 9 & Suryono, S.Ag & Sidorejo & Pensioner \\
\hline 10 & H. Suryono, M.Pd & Air Putih Lama & $\begin{array}{l}\text { Head of Office of Religious } \\
\text { Affairs South Curup }\end{array}$ \\
\hline 11 & Izhar Syafawi, S.Ag & Air Bang BTN & Pensioner \\
\hline 12 & Drs. H. Rasid Jamak & Sukaraja & Pensioner \\
\hline 13 & Tegu Ati, M.Pd & Batu Galing & $\begin{array}{l}\text { Ministry of Religious Affairs } \\
\text { RL }\end{array}$ \\
\hline 14 & Drs. Zulkifli & Air Bang BTN & Pensioner \\
\hline 15 & Irsan Sidik, S.Ag & $\begin{array}{l}\text { Talang Rimbo } \\
\text { Baru }\end{array}$ & $\begin{array}{l}\text { Ministry of Religious Affairs } \\
\text { RL }\end{array}$ \\
\hline 16 & Drs. Bahtiar Iman & Tunas Harapan & $\begin{array}{l}\text { Office of Religious Affairs } \\
\text { Curup Utara }\end{array}$ \\
\hline 17 & H. Usep Saifuddin, M.Pd & Sidorejo & Head of MTs Islamic Centre \\
\hline 18 & Drs. H. Amrullah & Timbulrejo & Pensiunan \\
\hline 19 & A. Kadir A.Ma & Teladan Village & $\begin{array}{l}\text { Office of Religion Affairs } \\
\text { South Curup }\end{array}$ \\
\hline 20 & Supianto, S.Ag & Animal Market & $\begin{array}{l}\text { Office of Religious Affairs } \\
\text { Central Curup }\end{array}$ \\
\hline 21 & Drs. Samiri & Air Rambai & $\begin{array}{l}\text { Office of Religious Affairs } \\
\text { Curup }\end{array}$ \\
\hline 22 & Fahamsyah, M.PdI & Sidorejo & $\begin{array}{l}\text { General Election } \\
\text { Commission Curup }\end{array}$ \\
\hline 23 & Drs. Bahtiar Jamil & Timbul Rejo & Teacher of MAN Curup \\
\hline 24 & Drs. H. Safruddin M.Pd.I. & Batu Galing & Lecturer of STAIN \\
\hline 25 & H. M. Ali Muhammad & $\begin{array}{l}\text { Agung Mosque } \\
\text { Curup }\end{array}$ & Priest of Agung Mosque \\
\hline 26 & Drs. H. Tarmizi Syam & $\begin{array}{l}\text { Air Sengak } \\
\text { Curup }\end{array}$ & Pensioner \\
\hline 27 & M. Syaropi, Sm.Hk & Adirejo & Pensioner \\
\hline 28 & Keruliman, S.Ag & Air Rambai & Employee \\
\hline
\end{tabular}

From the data above only a few da'i, there are still many da'i who have not registered in kemenag Rejang Lebong, this da'i task not only fill the kultum but also to fill the lecture in ta'lim assembly, lecture night of Friday and lectures on a grand tabligh.

STAIN Curup Cooperation with Local Government Rejang Lebong: 
Safari Ramadhan; Ramadhan Safari is an activity of STAIN Curup $\quad .1$ in Ramadhan month by way of STAIN Curup Campus device and lecturer and also Local Government of Rejang Lebong visited several mosques in order to socialize campus and also give enlightenment about Islam. Socialization and religious lectures are delivered after the prayers and before tarawih prayers, the goal is for people to include their children to religious schools

such as STAIN Curup.

2. Safari Friday; Safari Friday is one of the activities of STAIN Curup to preach to the community, by sending several lecturers to serve as preachers on Friday in some mosques in Rejang Lebong.

\section{Supporting Factors and Da'wah Obstacle in Rejang Lebong Regency}

It is an undeniable fact that Islam has survived centuries in this archipelago, with all its strengths and weaknesses. Muslims as the majority population from time to time have not changed much. This means that the endurance of Islam in the struggle with various challenges is remarkable. But on the other hand, there are still quite a lot of weaknesses found among Muslims in the context of da'wah. The thing that is delematic is that Muslims as the majority population in Indonesia, but minus the quality. According to Ahmad Syafii Maarif, the three main points of weakness and backwardness of the people, namely poverty, ignorance and backwardness. ${ }^{21}$ Label majority with minus quality, this will worsen the image of Islam, as well as the image of Indonesia in the eyes of the world, if not immediately addressed through a multidimensional and integrative approach.

Da'wah on the internal level is the embodiment of various weaknesses among Muslims. Therefore it needs to be identified so it can be improved in the future for the progress of the people and the glory of Islamic civilization. Internal challenges can also be engineered by external parties in order for Muslims to become weak and helpless. In the context of the da'wah challenge, Hamka sees that Muslims have four

${ }^{21}$ Ahmad Syafii Maarif, Islam dalam Bingkai Keindonesiaan dan Kemanusiaan : Sebuah Refleksi Sejarah, Bandung: Mizan, 2009), p. 243. 
major diseases of weak faith, selfishness, drunken powers and uncontrolled passions. ${ }^{22}$

First, the weak spirit to sacrifice for the sake of religion. This also indirectly shows the weakness of faith among Muslims. According to Hamka, weak faith is a humiliation, which can lead to bad character, fear of the enemy or cowardice and selfishness. Every Muslim should have the identity as described in Surat al-Fath [48], 29 verse, which is firm against the unbelievers and affectionate fellow Muslims.

Second, selfish and indifferent to the rights of others, such as the rights of friends, and neighbors. Third, drunk authority. Fourth, uncontrolled lust. Beside, seeing the many weaknesses of Muslims, Hamka also advised da'i not to raise the issue of khilafiah, because it can lead to divisions among Muslims. In addition, it is necessary to develop an optimism attitude in achieving the success of Islam. Attitudes like this can be developed with the belief that the Qur'an has a perfect concept.

Then M. Natsir also saw some weaknesses of Muslims. First, Muslims are the majority population in Indonesia, but the potential or human resources (HR) owned is still low. So is the understanding of Islam. According to M. Natsir, understanding of Islam is influenced by Western perception. In addition, there is still a narrow understanding that surrounds Muslims, which encourages dichotomy, extremism, contradicts Islam with Pancasila as the basis of the state and other attitudes that are not conducive to the progress of Islam. In addition, some Muslim politicians are secularists, and they are not partly responsible for the progress of Islam. ${ }^{23}$

decline of Muslims in education, economy and health. About the role and economic life of Muslims, M. Natsir said:

The economy, obviously very striking. In the past, Muslims had at least an asset in the field of economic development. The middle class of the economy in the past was generally from among the people. However, the existing developments show that people are "thrown" from the national economic arena.

\footnotetext{
22 Hamka, Prinsip dan Kebijaksanaan Dakwah, p. 25 dan 29.
}

23 M. Natsir, Fiqhud Dakwah, (Jakarta: Media Dakwah), p.110 
Third, the weakness in the management of the potential of Muslims. Essentially, the potential of Muslims continues to increase from time to time. However, the potential is not maintained and utilized optimally for the benefit of Islam. Whereas in increasing da'wah is needed the role and cooperation of Muslims in various fields. In addition, according to M. Natsir, some of Muslims are reluctant, do not dare to take risks and not aware of the actions of external parties.

The attitude above, according to the opposite figure of Soemarno's polemic, arises because of the love of the world (hubb al-dunya) is excessive, even though it is contrary to his conscience. According to him this condition is very different from the attitude of society in pre and post-independence era. Excessive world love diseases, also influenced by advances in science and technology and the impact of modernization.

Fourth, weakness in the field of advancing the Islamic generation for leadership estafeta. According to M. Natsir, this is because the attitude does not care between the older generation to the younger generation. As a result, paralysis and weakness affect the continuation of future leadership. To overcome this condition, M. Natsir suggested that the younger generation of Islam, through organizations or missionary organizations hold meetings to examine the issue seriously, analyze the situation and develop a common perception. However, because it is a sensitive issue, it must be careful and not too much touted. ${ }^{24}$

On the other hand, the weakness of da'wah lies in the da'i and da'wah organization in its management. The existence of da'i and da'wah organization can be seen as a strength, but on the other hand today there are still many weaknesses. The weaknesses are: (a). The lack of encouraging cooperation among da'wah organizations. (b). The competence of da'i is not enough. (c). Da'wah activities have not touched all aspects of people's lives. (d). The map of da'wah is unclear. (e). The weakness of da'wah management which is not professional image handling da'wah activities. (f). The issue of unspecified sources of da'wah funds and a series of other weaknesses can be sorted. The following discussion attempts to analyze four weaknesses that are considered very basic.

24 Abdul Aziz Thaba, Islam dan Negara dalam Politik Orde Baru, (Jakarta: Gema Insani Press, 1996), p. 265. 
First, the cooperation between da'wah organizations is considered important enough to overcome the weaknesses both at the level of concept and at the level of operational da'wah. Because with the realization of good cooperation, it is more possible to understand each other, mutual learning and mutual help, and avoid overlapping da'wah activities against the same object. For the initial stage for example, a meeting between the leaders of the organization (top leader).

Second, the weakness of da'wah lies in the power of da'i related to quality, professionalism and competence. ${ }^{25} \mathrm{Da}^{\prime} \mathrm{i}$ is the first and main element in the process of da'wah activities. Therefore its existence is decisive in planning, implementation and in achieving the goal of da'wah. Given that, then at all times are needed da'i a qualified and professional and able to provide an alternative answer to the problems faced by people in the current era of globalization.

Third, da'wah activities have not touched various aspects of community life. Portraits of da'wah so far, more dominant in oral form such as khutbah, lectures and the like. The themes discussed still focus on belief and worship issues and struggle around the issues of halal and haram, heaven and hell, while other aspects of Islam are very wide often overlooked. Da'wah in modern terminology is the reconstruction effort of society which includes improvement of life in the field of social welfare, education, law, politics, economy, cultural life, development of science, technology and mental spiritual. ${ }^{26}$ Therefore, the themes of da'wah should be more diverse in accordance with the problems and demands of people's lives.

Fourth, the map of da'wah is unclear. If we look at the diversity of life issues of the people, then the activity of da'wah is not a casual activity or a breakthrough and then produce results. However, da'wah activities require good handling, management and da'wah planning based on

25 The competence of da'i is divided into three things, namely substantive competence, methodological competence and technical competence. Substantive competence associated with the mastery of science keislamam a broad and deep and noble character. Methodological competence emphasizes the ability of da'i in planning and implementing da'wah according to objective conditions of da'wah goals. While technical competence, is the ability to master the technology that supports the success of da'wah. See, Abdullah, Insight of Da'wah, p. 45.

26 Sukrianto (dkk), Pergumulan Pemikiran Dalam Muhammadiyah, (Yogyakarta: Sipress, 1990), p. 127. 
objective conditions of the people. Then the next problem is how to formulate a da'wah policy strategy based on planning based on the results of research da'wah and then poured in the map of da'wah.

On the other hand, the weak point of Muslims on the political aspect. The fact that Muslims are the majority in the census, a minority in role and quality. So if political intelligence is one of the weak points of the people, then da'wah should be oriented to efforts to educate people's politics. There is a fundamental problem that needs to be straightened out that in a vision, politics have not been agreed as an instrument that is an integral part of da'wah and amar makruf nahi mungkar. According to Eep Saefullo Fatah there are 25 types of mistakes in understanding and political practice among people, among them the excitement in ritual territory, silent in the political area and see politics as black and white. ${ }^{27}$

\section{Conclusion}

Problems often encountered in Structural is the absence of a standard system and policies and agreed as a work guide, there is no policy for handling da'wah specifically in areas that have special conditions (housing or certain settlements), have not been division of tasks and responsibilities in spesific.

1. Problems often encountered in Human Resource Management

- Human resource distribution has not considered regional needs.

- The distribution of human resources is not evenly distributed.

- The absence of systematic distribution of human resources arrangements that result in the accumulation of human resources in certain areas or on certain elements of society.

2. The main problem in Arrangement of Da'wah Area

- The absence of arrangement of da'wah area. Da'wah elements move independently not on a single command.

- Has not yet had adequate understanding what are the main tasks and functions that a person must perform in the da'wah area.

- There is no guidance on da'wah work in da'wah area. For example a concept of community da'wah.

27 Eep Saefulloh Fatah, Kalangan Islam: Dari Statistik ke Politik? dalam Dhurorudin Mashad, Akar Konflik Politik Islam di Indonesia, (Jakarta: Pustaka Al-Kautsar, 2008), p.xiv. 
- The absence of a monitoring system for preachers placed in da'wah areas. This can make the work of da'i in a region can be measured and evaluated properly.

The solutions that can be submitted in this research are:

1. Structural Solutions

- Socialize to the da'i about who is the rightful party and is entitled to take the highest policy in a da'wah area.

- Make arrangements on the policy making mechanism.

2. Human Resource Management Solutions

- Distributing human resources with a particular system and or methodology that can accommodate structural and territorial needs.

- The existence of a work guide that includes clarity of duties and responsibilities.

3. The Set Up Solution of Da'wah

- Socialize to da'i in the da'wah area regarding the legitimate parties and is entitled to take policy in the da'wah area

- Make arrangements on the mechanisms of policy making in the da'wah area.

- Creating a network that can access all elements of community da'wah

\section{Bibliography}

Ahmed, Akbar S. Posmodernisme: Bahaya dan Tantangan Bagi Islam, Terj. M. Sirozi Bandung: Mizan, 1993.

Al-Faruqi, Ismail R. dan Lois Lamya al-Faruqi, Atlas Budaya: Menjelajah Khazanah Peradaban Gemilang, Terj. Ilyas Hasan. Bandung: Mizan

Ali, A. Mukti Beberapa Persoalan Agama Dewasa Ini, Jakarta: Rajawali Pers, 1987.

Arnold, Thomas W. The Preaching of Islam, Terj. A. Nawawi Rambe. Jakarta: Wijaya,1985.

Aziz, Moh Ali Ilmu Dakwah, Jakarta: Kencana Prenada Media Group, 2004.

Amin, Samsul Munir, Rekonstruksi Pemikiran Dakwah Islam, Jakarta: 2008.

Aziz, Jum'ah Amin Abdul, Fiqh Dakwah; Studi atas Berbagai Prinsip dan Kaidah yang Harus Dijadikan Acuan dalam Dakwah Islamiah, Solo: Karya, 2011. 
Arikunto, Suharsimi. Prosedur Penelitian Suatu Pendekatan Praktek. Jakarta : Rineka Cipta, 2002.

Burhan. Analisis Data Penelitian Kualitatif. Jakarta: PT Rahagrafindo Persada, 2003.

Hamka, Sejarah Umat Islam, Singapura: Pustaka Nasional, 2005.

Ibnu Hammad, Kata Pengantar, dalam Syarif Hidayatullah dan Zulfikar S. Dharmawan, Islam Virtual: Keberadaan Dunia Islam di Internet, Jakarta: MIFTA, 2004.

Jurdi, Syarifuddin. 1 Abad Muihammadiyah, Jakarta: Kompas Media Nusantara.

Kuntowijoyo, Paradigma: Interpretasi Untuk Aksi, Bandung : Mizan, 1991.

Mahmud, Ali Abdul Halim. Dakwah Fardiyah, terj. As`ad Yasin. Jakarta: Gema Insani Press. 1995.

Madjid, Nurcholis. Islam Doktrin dan Peradaban, Jakarta: Yayasan Wakaf Paramadina, 1992.

Masy'ari, Anwar. Butir-Butir Problematika Dakwah, Surabaya : Bina Ilmu. 1993.

Moleong, Lexy J. Metodologi Penelitian Kualitatif. Bandung: Remaja Rosdakarya, 2007.

Natsir, M. Fiqhud Dakwah, Jakarta: Media Dakwah.

Nawawi, Hadari. Manajemen Sumber Daya Manusia Untuk Bisnis Yang Kompetitif, Cetakan Ke-4, Gajah Mada Univercity Press, Yogyakarta, 2005.

Quthb, Sayyid, Fî Zhilâl al-Qur'ân, vol. i. Beirut: Dâr al-Syuruq, 1986

Rais, M. Amien, Cakrawala Islam, Bandung : Mizan, 1991.

Sugiyono. Metode Penelitian Administrasi. Bandung : Alfabeta, 2007.

Sudijono, Anas. Evaluasi Pendidikan. (Jakarta : Raja Grafindo, 1996.

Tarigan, Azhari Akmal, Jalan Ketiga Pemikiran Islam HMI, Bandung: Citapustaka Media Perintis, 2008.

Yakam, Fathiy. Menggapai Sukses Perjuangan Da'i, Solo: Romadhoni, 1990. 